Fitzsimmons, J. R., and Kozelka, F. L. (1950). Effects of BAL in tissue distribution and excretion of mercury in acute mercury poisoning. F. Pharmacol. exp. Ther., 98, 8.

Longcope, W. T., Luetscher, J. A., Jun, Calkins, E., Grob, D., Bush, S. W., and Eisenberg, H. (I946). Clinical uses of 2,3-dimercaptopropanol (BAL). XI. The treatment of acute mercury poisoning by BAL. F. clin. Invest., 25, 557-567.

Moeschlin, S. (1964). Klinik und Therapie der Vergiftungen, p. ro4. Thieme, Stuttgart.

Swensson, A., and Ulfvarson, U. (1967). Experiments with different antidotes in acute poisoning by different mercury compounds. Intern. Arch. Gewerbepath. Gewerbehyg., 24, $12-50$.

\title{
Stress Fracture of the Femur: A Work Accident
}

\author{
I. A. MANSOOR \\ From Rotschild Hospital, Haifa, Israel
}

Stress fracture has been well documented. Most cases reported occur in young conscripts of the armed forces (Bingham, 1945; Mann, 1945; Wolfe and Robertson, 1945). Other causes include the hard training programme of athletes, sport (Devas and Sweetnam, 1956; Kitchin, 1948; Devas, 1958; Miller, 1960; Devas, 1963), ballet dancing (Burrows, 1956), and ice-skating (Ingersoll, 1943). Presented here is a case of stress fracture of the femur caused by hard physical labour.

\section{Case History}

M.D., a casual labourer of 35 years of age, obtained employment during the construction of a building. His work entailed the continuous carrying of heavy loads from the ground to the upper floors. Three weeks after starting work he began to feel pain in the lower left thigh during work, which was at first relieved by rest. This gradually became worse and he sought medical advice on December 17, 1965. Radiographs were normal and a muscle strain was diagnosed. He continued working in order not to be discharged from the pay-roll. The pain became more persistent and severe until, by the end of a further three weeks, he could not bear weight fully on the leg, and limped. Three days before admission to hospital, on January 6,1966 , his left foot caught on the edge of a stair at home. He did not fall, but the pain suddenly became excruciating and he could bear no weight on it.

Examination showed the usual signs of fracture but without deformity. Radiographs (Fig. I) showed a fracture with minimal displacement.

Investigation showed: $\mathrm{Hb}$ I4.5 g. \%. W.B.C. 7,700/ c.mm. (band $4 \%$, segment $72 \%$, monocytes $6 \%$, lymphocytes I $8 \%$ ); E.S.R. $32 \mathrm{~mm}$. in one hour (Westergren); urea $33 \mathrm{mg}$. \%; blood sugar II $8 \mathrm{mg}$. \%; total serum proteins 7 g. $\%$ (albumin 4 g. $\%$ ); acid phosphatase 0.3 unit, alkaline phosphatase 2.0 units; potassium 4.5 $\mathrm{mEq} / \mathrm{l}$., sodium $140 \mathrm{mEq} / \mathrm{l}$., chlorides $100 \mathrm{mEq} / \mathrm{litre}$.

He was given a single hip spica without anaesthesia

Received for publication October 26, 1967. and was discharged on January 14. His convalescence was uneventful and on March 6 he was allowed to bear weight on the plaster. On April 14 the plaster was removed. Clinically and radiologically (Fig. 2) the fracture had united.

\section{Discussion}

The insidious onset, the nature of his work, the trivial cause of the fracture, plus the lack of rotational deformity and little displacement occurring in a bone of normal texture and density, point to a diagnosis of stress fracture. Freiberger and Mayer (1964) report a case of bilateral stress fracture of the first rib in a plasterer who spent many hours plastering ceilings, holding a board of wet plaster in his left hand and a trowel in his right. This is the only other case of occupational stress fracture mentioned in the literature.

\section{REFERENCES}

Bingham, J. A. W. (1945). Stress fracture of femoral neck. Lancet, 2, 13-14.

Burrows, H. J. (1956). Fatigue fracture of the middle of the tibia in ballet dancers. $\mathcal{F}$. Bone $\mathcal{F}$ t Surg. 38B, 83-94.

Devas, M. B. (1958). Stress fractures of the tibia in athletes or 'shin soreness'. Ibid., 40B, 227-238.

- (1963). Stress fractures in children. Ibid., 45B, 528-54I. , and Sweetnam, R. (1956). Stress fractures of the fibula -a review of fifty cases in athletes. Ibid., 38B, 818-829.

Freiberger, R. H., and Mayer, V. (1964). Ununited bilateral fatigue fractures of the first ribs. Ibid., 46A, 615-618.

Ingersoll, C. F. (1943). Ice skater's fracture: a form of fatigue fracture. Amer. F. Roentgenol., 50, 469-479.

Kitchin, I. D. (1948). Fatigue fracture of the ulna. F. Bone ft Surg., 30B, 622-623.

Mann, T. P. (1945). Fatigue fracture of the tibia. Three cases at a Naval training establishment. Lancet, 2, 8-10.

Miller, J. E. (1960). Javelin thrower's elbow. f. Bone ft Surg., 42B, 788-792.

Wolfe, H. R. I., and Robertson, J. M. (1945). Fatigue fracture of femur and tibia (in young men undergoing intensive training). Lancet, 2, I I-13. 

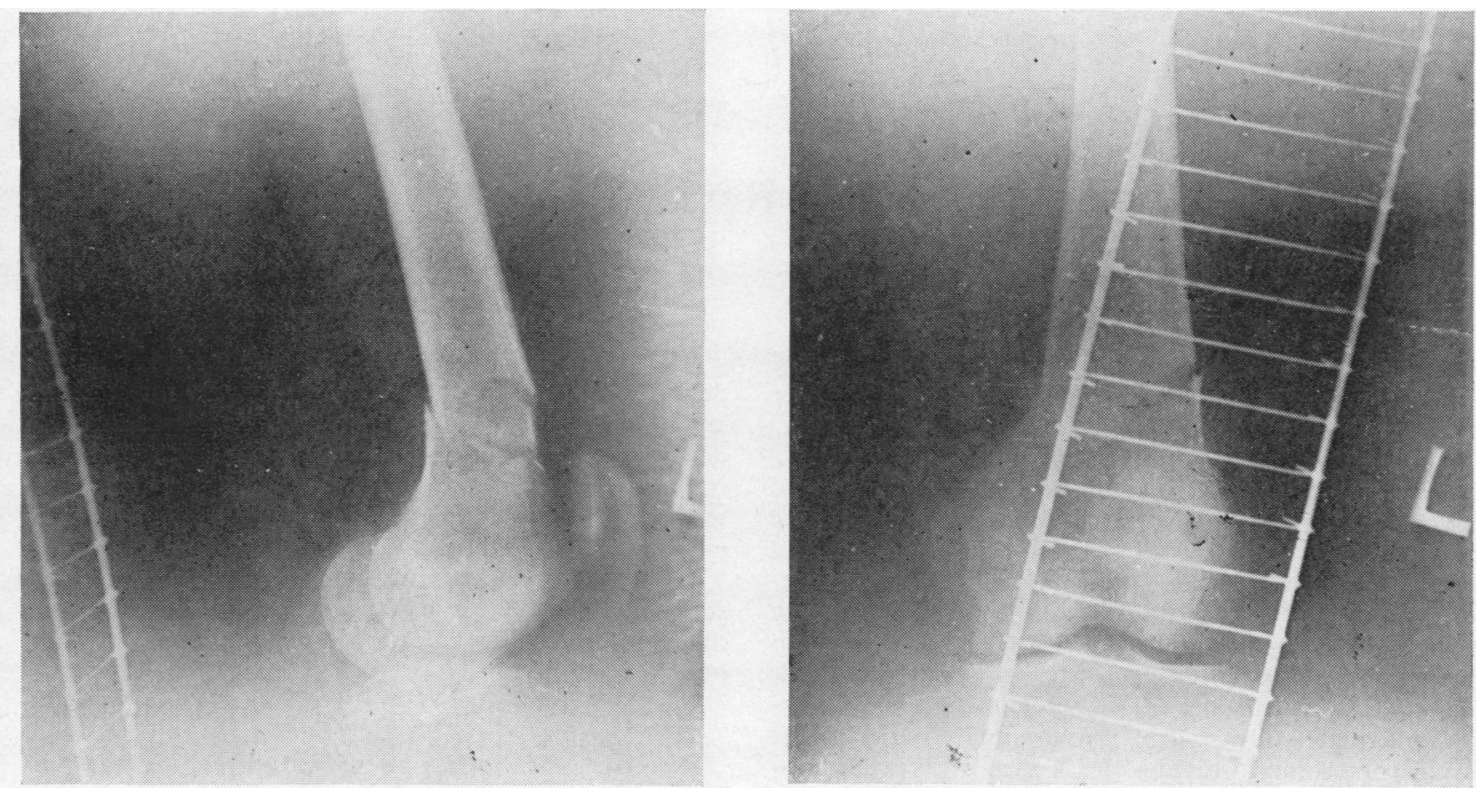

FIG. I. Radiographs of left femur on admission in January.
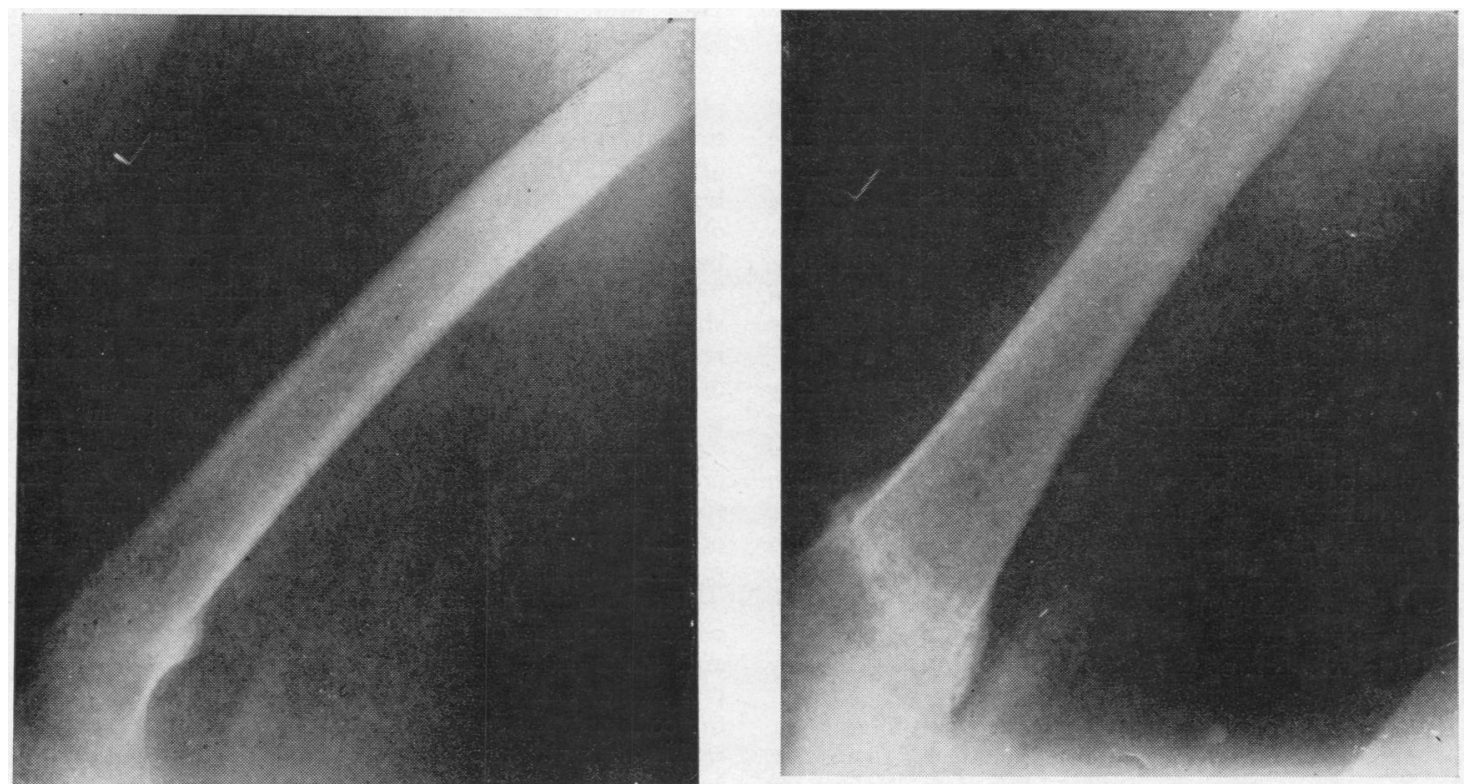

FIg. 2. Radiographs of left femur after removal of plaster in April. 